\title{
Love at First Site
}

I grew up on Mount Desert Island, and after leaving for college, I always hoped I would be able to return. There is a saying that "People in Maine have salt water in their veins."

It was not an environment where people are highly educated. I was the second person in my high school to ever get a postgraduate degree. My mother was a teacher and my father a lobster fisherman, but they encouraged me to go to college. They never said "If you go to college," but rather, "When you go to college." It was always assumed that I would go.

I remember my first biology course at Mount Holyoke College, a liberal arts college in Massachusetts. When it came to the session on genetics, it was love at first site. What drew me to genetics was its precision and order-that you can predict how traits are inherited from one generation to another. I was also fascinated by how people are shaped by their genes and how important genetics is to human health.

I decided early on that I wanted to do biomedical research by providing genetic resources to other scientists. I have succeeded in building a strong program to develop mouse models of disease. There are now several hundreds of our models out there that people are using. In this way, my work gets expanded many times. It is a way of having a much bigger impact than if I were working on an individual disease.

The mouse model of Down syndrome that we published in 1995 received a lot of publicity. In 2002, I was named "Researcher of the Year" by the National Down Syndrome Society in recognition of that work.

People with Down syndrome have three copies of chromosome 21. Scientists had tried to create mice with three copies of the mouse homolog of human chromosome 21 , but the mice died before birth. We took a different approach. We created a mouse with three copies of only a portion of the chromosome, called a segmental trisomy. The mice survived to adulthood and mimicked many of the learning and behavioral features of Down syndrome.

It was a challenge, because no one had been able to create an animal model of Down syndrome, and we did not know whether our approach would work. The National Institute of Child Health and Human Development (NICHD) at the National Institutes of Health had put out a call for proposals for making a mouse model of Down syndrome. Initially I did not apply, and people from NICHD contacted me to find out why. I told them I would use a shotgun approach that might need to be funded for many years without producing any results. I

planned to irradiate mice to make chromosome breaks and then identify in the offspring chromosomal rearrangements that might lead to trisomy. They encouraged me to write a proposal, and it got funded. I had funding for about 5 years before I made the mouse model.

I am still doing some research using the Down syndrome mouse. Most researchers are focusing on behavior, learning, and brain systems, but I am looking at more basic questions. Why is growth delayed? Why are males sterile? What are the genes that regulate the different reproductive levels of females? It is not very exciting work and requires long-term studies, but the results are important. I am in a position where I can do this characterization research that is not cutting-edge molecular analysis.

I think my life is very hectic. After my husband died about 10 years ago, I threw myself into my work and tried to be busy every minute. Now I would like to slow down. In the past year, I have been taking some weekends off and doing things outside of work. I have many interests.

I live in the house my aunt Ruth Moore built. She was a novelist and poet. The house sits on 20 acres of land. It used to have a little farm and an apple orchard. I am now renovating the property and restoring it to its original state. I am doing all the work myself. I like to do things with my own hands, because I can see immediate results and progress. In a way, the sense of accomplishment is more tangible than in science.

As told to Laura Bonetta, a science writer based in Bethesda, MD. 